\title{
PENYEBAB KEBAKARAN HUTAN DI KAWASAN HUTAN PENDIDIKAN GUNUNG WALAT, JAWA BARAT
}

\author{
Forest Fire Causes in Gunung Walat Educational Forest, West Java \\ Ati Dwi Nurhayati ${ }^{{ }^{*}}$ dan Aldi Yusup ${ }^{1}$
}

(Diterima Februari 2019/Disetujui November 2019)

\begin{abstract}
Forest fires resulted from human activities such as land preparation by using fire. Dry season, forest fire hazard, low awareness of local communities as well as limited infrastructure for fire control are all the factors related to the occurrence of forest fires. The objectives of this research is to identify forest fire causes in Gunung Walat Educational Forest. Forest fire in Gunung Walat Educational Forest over the last five years (2011-2015) occurred in 2012, 2014 and 2015. Forest fire in 2015 had the highest frequency that is three times with the area burnt reached 8.4 ha. The rainfall in Cibadak District is relatively high but it contain some months with the low rainfall. There is a correlation of some parameters that analyzed between characteristic of respondent with the occurrence of forest fire. Characteristic of respondent such as employment, income and distance to forest in Batununggal village showed a positive correlation to the forest fire occurrence.
\end{abstract}

Key words: characteristic of respondent, forest fire, rainfall

\section{PENDAHULUAN}

Berdasarkan data Statistik Kementerian Kehutanan laju deforestasi hutan Indonesia periode 2011-2012 sebesar 613480.7 hektar (Kemenhut 2013). Salah satu faktor yang menyebabkan deforestasi hutan adalah kebakaran hutan. Kebakaran Hutan dan Lahan yang selanjutnya disebut Karhutla adalah suatu peristiwa terbakarnya hutan dan/atau lahan, baik secara alami maupun oleh perbuatan manusia, sehingga mengakibatkan kerusakan lingkungan yang menimbukan kerugian ekologi, ekonomi, sosial budaya dan politik (PermenLHK No 32 Tahun 2016).

Penyebab kebakaran hutan dan lahan didefinisikan sebagai sesuatu yang bersifat alami maupun perbuatan manusia yang menyebabkan terjadinya proses penyalaan serta pembakaran bahan bakar hutan dan lahan. Kebakaran hutan terjadi disebabkan oleh bersatunya ketiga unsur pembentuk api, yaitu bahan bakar, oksigen dan panas. Musim kemarau yang kering dan panas. kondisi alam serta prilaku manusia dalam menggunakan api menyebabkan kebakaran hutan menjadi lebih mudah. Menurut Syaufina (2008) kebakaran hutan dan lahan di Indonesia faktor penyebabnya $99 \%$ adalah manusia baik disengaja maupun tidak sengaja, sedang faktor alam hanya sebesar $1 \%$ saja, contohnya api digunakan dalam pembukaan lahan untuk pertanian. Penyebab kebakaran hutan secara tidak langsung yaitu penguasaan lahan, alokasi penggunaan lahan, insentif/disinsentif ekonomi, degradasi hutan dan lahan, dampak dari perubahan

\footnotetext{
${ }^{1}$ Departemen Silvikultur, Fakultas Kehutanan Institut Pertanian Bogor

* Penulis korespondensi:

E-mail: awinur@yahoo.com
}

karakteristik penduduk, dan lemahnya kapasitas kelembagaan (Applegate dan Suyanto 2001).

Wilayah Hutan Pendidikan Gunung Walat rawan terjadi gangguan hutan seperti kebakaran hutan karena keberadaannya yang tidak jauh dari pemukiman warga. Hal tersebut dapat mempengaruhi fungsi hutan secara ekologi sampai ekonomi. Dengan demikian perlu dilakukan penelitian untuk mengidentifikasi penyebab kebakaran hutan di kawasan Hutan Pendidikan Gunung Walat, Jawa Barat, untuk mempelajari aktivitas masyarakat sekitar hutan secara langsung atau tidak langsung. Penelitian ini bertujuan untuk mengidentifikasi penyebab kebakaran hutan di sekitar Hutan Pendidikan Gunung Walat, Jawa Barat.

\section{METODE PENELITIAN}

\section{Waktu dan Lokasi Penelitian}

Penelitian dilakukan di Desa Hegarmanah, Desa Cicantayan dan Desa Batununggal yang berada di sekitar kawasan Hutan Pendidikan Gunung Walat. Penelitian ini dilaksanakan pada bulan Januari 2016 sampai dengan bulan Februari 2016.

\section{Alat dan Bahan}

Alat yang digunakan dalam penelitian adalah perangkat laptop, lembar kuisioner, kamera dan perangkat komputer seperti SPSS 17.0, Microsoft Word dan Microsoft Excel. Bahan yang diperlukan dalam penelitian ini, seperti data kejadian/frekuensi kebakaran hutan bulanan selama 5tahun terakhir, data kejadian kebakaran hutan tahunan selama 5 tahun terakhir dan data curah hujan 5 tahun terakhir. 


\section{Prosedur Penelitian}

\section{Penentuan Lokasi Penelitian}

Metode yang digunakan dalam penentuan lokasi penelitian adalah metode purposive sampling yaitu pemilihan lokasi penelitian berdasarkan wilayah dengan jarak terdekat dari kawasan Hutan Pendidikan Gunung Walat.

\section{Teknik Wawancara}

Responden ditentukan dengan menggunakan metode snowball, menurut Silalahi (2002) metode snowball adalah penunjukan terlebih dahulu seseorang yang dianggap mampu memberikan informasi (key informan) dan atas rekomendasinya dapat menunjuk responden lainnya untuk diwawancarai. Penunjukan key informan dilakukan oleh kepala desa pada masing-masing desa yang telah ditentukan sebagai lokasi penelitian. Jumlah responden minimal dalam penelitian sebanyak 30 orang untuk mewakili seluruh populasi (Singarimbun et al 1995). Dengan demikian jumlah responden yang diwawancarai sebanyak 90 orang yang terdiri dari 3 desa dengan masing-masing 30 responden dari tiap desa yang terpilih.

\section{Analisis Data}

Metode analisis data yang digunakan adalah uji Chi Square dan metode analisis deskriptif. Uji Chi Square dilakukan untuk melihat hubungan antara karakteristik responden dengan kejadian kebakaran hutan di Hutan Pendidikan Gunung Walat. Uji Chi Square adalah membandingkan antara fakta yang diperoleh dari hasil observasi dan fakta yang didasarkan secara teoritis (Supangat 2010). Analisis deskriptif digunakan untuk mendeskripsikan secara lebih luas dari hasil wawancara yang telah dilakukan.

\section{Kondisi Umum Lokasi Penelitian}

Kawasan Hutan Pendidikan Gunung Walat secara geografis terletak antara 6 54'23" 6 65 '35" LS dan $106^{\circ} 48^{\prime} 27^{\prime \prime}-106^{\circ} 50^{\prime} 29^{\prime \prime}$ BT dan secara administratif terletak dalam wilayah Kecamatan Cibadak Kabupaten Sukabumi. Sedangkan secara administratif kehutanan termasuk dalam wilayah BKPH Gede Barat, KPH Sukabumi, Perum Perhutani Unit III Jawa Barat dan Banten. Luas wilayah hutan 359 ha. Hutan Pendidikan Gunung Walat terdiri dari tiga blok yaitu Blok Timur (Cikatomas) seluas 120 ha, Blok Barat (Cimenyan) seluas 125 ha, dan Blok tengah (Tangkalak) seluas 114 ha. Kawasan Hutan Pendidikan Gunung Walat sebelah utara berbatasan dengan Desa Batununngal dan Desa Sekarwangi, sebelah timur berbatasan dengan Desa Cicantayan dan Cijati, sebelah selatan dan barat berbatasan dengan Desa Hegarmanah.

\section{HASIL DAN PEMBAHASAN}

\section{Kejadian Kebakaran Hutan}

Kejadian kebakaran hutan di Hutan Pendidikan Gunung Walat selama lima tahun terakhir (2011-2015) terjadi pada tahun 2012, 2014 dan 2015. Berdasarkan hasil wawancara dengan pihak HPGW kebakaran hutan pada tahun 2015 memiliki frekuensi yang paling tinggi yaitu sebanyak tiga kali dengan luas kebakaran mencapai 8.4 ha. Curah hujan pada tahun 2015 terbilang sangat besar yaitu $2720 \mathrm{~mm}$. Kejadian kebakaran hutan tertinggi kedua terjadi pada tahun 2012 dengan frekuensi satu kali kebakaran dengan luasan terbakar 3.7 ha sedangkan pada tahun 2014 terjadi satu kali kebakaran dengan luasan terbakar 2.3 ha. Curah hujan pada tahun 2012 merupakan curah hujan yang paling rendah yaitu $2269 \mathrm{~mm}$ sedangkan curah hujan pada tahun 2014 yaitu sebesar 2879 mm. Pada tahun 2011 dan tahun 2013 tidak ada kejadian kebakaran di HPGW. Adapun curah hujan pada tahun 2011 adalah sebesar $2300 \mathrm{~mm}$ dan pada tahun 2013 adalah sebesar 2993 mm. Rata-rata curah hujan tahunan di Kecamatan Cibadak, Sukabumi selama lima tahun terakhir (20112015) yaitu $2632.2 \mathrm{~mm}$ yang menunjukan bahwa Hutan Pendidikan Gunung Walat termasuk kawasan yang tidak rawan terhadap kebakaran hutan karena memiliki curah hujan diatas $2000 \mathrm{~mm}$ per tahun (Septicorini 2006).

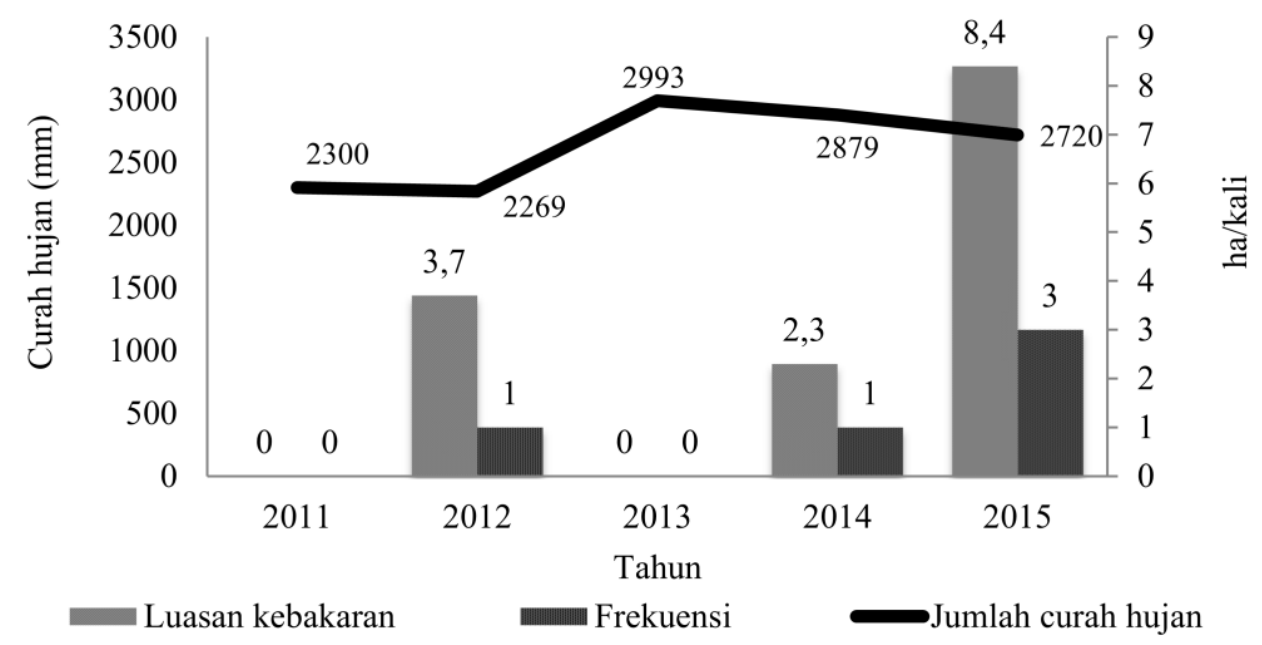

Gambar 1 Luas dan frekuensi kebakaran di Hutan Pendidikan Gunung Walat serta jumlah curah hujan di Cibadak, Sukabumi 
Grafik luasan dan frekuensi kebakaran di Hutan Pendidikan Gunung Walat serta jumlah curah hujan di Cibadak selama lima tahun terakhir (2011-2015) dapat dilihat pada Gambar 1.

Faktor penyebab terjadinya kebakaran hutan dan lahan bukanlah iklim. Iklim mempengaruhi dalam hal menentukan jumlah total bahan bakar yang tersedia, musim kebakaran yang panjang, mengatur kadar air dan flamabilitas dari bahan bakar mati, serta mempengaruhi proses penyalaan dan penjalaran kebakaran hutan (Syaufina 2008). Tinggi rendahnya intensitas curah hujan berpengaruh pada kejadian kebakaran hutan. Peningkatan kebakaran hutan terjadi pada bulan-bulan dengan curah hujan yang rendah (kurang dari $60 \mathrm{~mm}$ ). Klasifikasi Schmidt dan Fergusson dalam Chaidir (2012) menyatakan bahwa curah hujan kurang dari 60 $\mathrm{mm}$ termasuk dalam bulan kering, 60 sampai $100 \mathrm{~mm}$ termasuk bulan lembab dan jika dalam satu bulan mempunyai jumlah curah hujan diatas $100 \mathrm{~mm}$ dikatakan bulan basah. Pada Gambar 2 dapat dilihat Curah hujan tiap bulan di Kecamatan Cibadak, Sukabumi pada tahun 2011-2015.

Berdasarkan Gambar 3 dapat dilihat bahwa di dalam curah hujan tahunan yang tergolong tinggi terdapat bulan-bulan kering. Curah hujan terendah terjadi pada bulan Agustus dan September di setiap tahun pada periode 2011 sampai 2015. Bulan Agustus dan September pada tahun 2011, 2012 dan 2014 bahkan tidak turun hujan sama sekali, sedangkan curah hujan tertinggi yaitu pada bulan November tahun 2015 sebesar 799 mm. Kejadian kebakaran hutan pada tahun 2012 dan 2014 terjadi pada bulan September dimana hujan tidak turun sama sekali pada bulan tersebut sedangkan pada tahun 2015 kejadian kebakaran terjadi pada bulan Juli, Agustus dan September dimana pada bulan tersebut curah hujan sangat kecil. Kejadian kebakaran di Hutan Pendidikan Gunung Walat terjadi pada bulan-bulan kering yaitu bulan Juli, Agustus dan September. Musim kebakaran hutan biasanya berhubungan dengan pola curah hujan. Menurut Syaufina (2008) menunjukkan bahwa peningkatan kebakaran hutan terjadi pada bulanbulan dengan curah hujan yang rendah (kurang dari 60 $\mathrm{mm})$.
Faktor-faktor cuaca seperti suhu, kelembaban, curah hujan, angin, dan stabilitas udara secara langsung mempengaruhi potensi terjadinya kebakaran hutan. Faktor lain seperti jangka musim kemarau yang lama berpengaruh pada pengeringan bahan bakar, sehingga secara tidak langsung dalam jangka pendek maupun jangka panjang mempengaruhi terjadinya kebakaran hutan. Kejadian kebakaran hutan di kawasan Hutan Pendidikan Gunung Walat disebabkan oleh aktivitas manusia baik itu disengaja maupun tidak disengaja. Semua pihak bertanggung jawab dalam pengendalian kebakaran hutan meliputi pencegahan,pemadaman dan penanganan pasca kebakaran. Dalam penerapannya pihak Hutan Pendidikan Gunung Walat sudah melakukan pencegahan seperti sosialisai tentang kebakaran hutan kepada masyarakat dan pembuatan sekat bakar hanya tidak ada papan peringatan yang berisikan informasi tentang kebakaran hutan. Alat pemadam kebakaran yang dimiliki oleh Hutan Pendidikan Gunung Walat tidak memadai untuk melakukan pemadaman kebakaran.

\section{Karakteristik Responden}

Pemilihan responden dilakukan di tiga desa yaitu Desa Hegarmanah, Desa Cicantayan dan Desa Batununggal dengan 30 responden pada setiap desa. Ketiga desa tersebut merupakan desa yang berbatasan langsung dengan kawasan Hutan Pendidikan Gunung Walat atau masyarakat sekitar menyebut desa penyangga Gunung Walat. Analisis identitas responden berdasarkan demografi berupa pendidikan, mata pencaharian, pendapatan, aksesibilitas dan luas kepemilikan lahan.

\section{Tingkat Pendidikan}

Responden dari ketiga desa yang dijadikan lokasi penelitian semuanya pernah menempuh pendidikan formal. Dominasi tingkat pendidikan di desa penelitian berbeda-beda. Desa Hegarmanah dan Desa Batununggal didominasi oleh responden dengan tingkat pendidikan formal Sekolah Menengah Pertama (SMP) yaitu masing-masing sebanyak 19 responden atau $63.33 \%$ dan

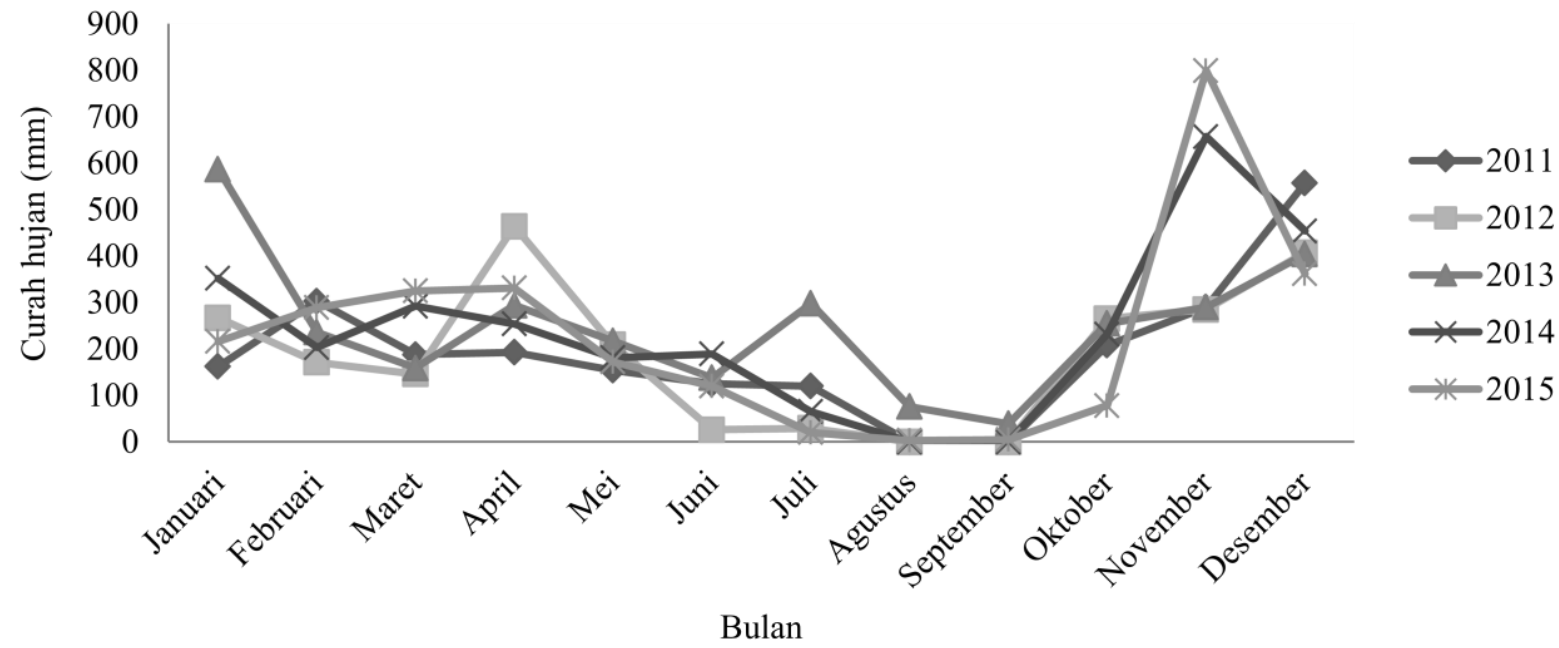

Gambar 2 Grafik curah hujan tiap bulan di Kecamatan Cibadak, Sukabumi tahun 2011-2015 
15 responden atau 50\%. Responden dengan tingkat pendidikan formal Sekolah Dasar (SD) adalah yang paling dominan di Desa Cicantayan yaitu 11 responden (36.67\%). Responden dengan tingkat pendidikan Perguruan Tinggi berjumlah 1 orang di Desa Hegarmanah dan 2 orang di Desa Cicantayan. Tingkat pendidikan akan mempengaruhi pola pikir masyarakat sekitar hutan tentang kesadaran pentingnya menjaga hutan.

\section{Mata Pencaharian dan Kondisi Sosial Ekonomi}

Mata pencaharian responden di desa penelitian berbeda. Wirausaha adalah mata pencaharian responden yang paling dominan di Desa Hegarmanah dan Desa Cicantayan yaitu sebanyak 17 responden $(56.67 \%)$ di Desa Hegarmanah dan 13 responden (43.33\%) di Desa Cicantayan. Mata pencaharian yang paling dominan di Desa Batununggal adalah petani dengan jumlah responden sebanyak 15 orang (50\%). Responden dengan mata pencaharian Pegawai Negeri Sipil (PNS) pada Desa Cicantayan sebanyak 2 orang $(6.67 \%)$ dan Desa Hegarmanah sebanyak 1 orang (3.33\%).

Tingkat pendapatan masyarakat di desa penelitan Hutan Pendidikan Gunung Walat digolongkan menjadi tiga golongan yaitu kurang dari Rp 500 000, Rp 500 000- 900000 dan lebih dari Rp 900 000. Berdasarkan Tabel 1 dapat dilihat responden di Desa Hegarmanah dan Batununggal didominasi oleh responden dengan penghasilan Rp. 500.00-Rp. 900.000 masing-masing sebanyak 16 responden $(53.33 \%)$ dan 13 responden (43.33\%). Responden di Desa Cicantayan di dominasi oleh responden dengan penghasilan lebih dari Rp. 900.000 sebanyak 20 orang (66.67\%). Responden dengan pendapatan terendah yang paling banyak berada di Desa Batununggal dengan jumlah responden sebanyak 9 orang (30\%). Tingkat pendapatan masyarakat sekitar hutan tergolong rendah jika dibandingkan Upah Minimum Kabupaten (UMK) Kabupaten Sukabumi tahun 2016 sebesar Rp 2.195.435 per bulan.

\section{Aksesibilitas}

Kerentanan kebakaran hutan salah satunya dipengaruhi oleh aksesibilitas. Berdasarkan Tabel 1 dapat dilihat bahwa responden di Desa Batununggal memiliki jarak yang paling dekat dengan kawasan hutan yaitu 22 responden $(73.33 \%)$ yang memiliki jarak kurang dari satu $\mathrm{km}$ dan $8(26.67 \%)$ responden berjarak tempuh antara satu sampai dua $\mathrm{km}$. Responden di Desa Hegarmanah yang berjarak tempuh kurang dari satu km berjumlah 8 responden $(26.67 \%$ ) dan sisanya berjumlah
22 responden $(73.33 \%)$ berjarak tempuh antara satu sampai dua $\mathrm{km}$. 11 responden $(36.67 \%)$ berjarak tempuh lebih dari dua $\mathrm{km}$ di Desa Cicantayan sedangkan 19 responden $(63.33 \%)$ lainnya berjarak tempuh antara satu sampai dua $\mathrm{km}$.

\section{Kepemilikan Lahan}

Responden di Desa Hegarmanah hanya ada 1 responden $(3.33 \%)$ yang memiliki lahan kurang dari 0,5 ha dan 1 responden $(3.33 \%$ ) yang memiliki lahan antara 0,5 sampai 1 ha. Sebanyak 3 responden (10\%) yang memiliki lahan kurang dari 0.5 ha dan 2 responden (6.67\%) yang memiliki lahan antara 0.5 sampai 1 ha di Desa Cicantayan. Responden di Desa Batununggal serupa dengan desa lainnya, hanya 4 orang responden yang miliki lahan seluas kurang dari 0.5 ha dan 2 orang responden yang memiliki lahan antara 0.5 sampai 1 ha.

\section{Hubungan antara Karakteristik Responden dengan Kejadian Kebakaran Hutan di Hutan Pendidikan Gunung Walat}

Pengukuran keeratan hubungan karakteristik responden dengan kejadian kebakaran hutan dilakukan dengan menggunakan uji korelasi Chi Square. Hasil pengujian Chi Square dapat dilihat pada Tabel 1.

\section{Hubungan antara tingkat pendidikan dengan kejadian kebakaran hutan}

Berdasarkan hasil uji Chi Square (Tabel 1), menunjukan bahwa tidak terdapat korelasi antara tingkat pendidikan di Desa Cicantayan dan Desa Batununggal dengan kejadian kebakaran hutan. Nilai $P$ value pada masing-masing kedua desa tersebut sebesar 0.255 dan 0.284. Desa Hegarmanah memiliki nilai P value sebesar 0.062 yang berarti tingkat pendidikan di desa tersebut memiliki korelasi dengan kejadian kebakaran pada selang kepercayaan 90\%. Desa Hegarmanah memiliki responden yang berpendidikan lebih rendah jika dibanding kedua desa lainnya hal ini sesuai dengan Harianto (2001) yang menyatakan bahwa tingkat pendidikan yang rendah akan mempengaruhi pola pikir dan pengetahuan dalam mengambil keputusan dan mengambil tindakan.

\section{Hubungan antara pekerjaan dan sosial ekonomi dengan kejadian kebakaran hutan}

Berdasarkan hasil uji Chi Square (Tabel 1), menunjukan bahwa pekerjaan responden di Desa Hegarmanah dan Desa Cicantayan tidak memiliki hubungan dengan kejadian kebakaran hutan dengan

Tabel 1 Hasil Uji Chi Square hubungan karakteristik responden dengan kejadian kebakaran hutan

\begin{tabular}{lccc}
\hline \multirow{2}{*}{ Karakteristik Responden } & \multicolumn{3}{c}{ Kejadian Kebakaran Hutan } \\
\cline { 2 - 4 } & Hegarmanah $(P$ Value $)$ & Cicantayan $(P$ Value $)$ & Batununggal $(P$ Value $)$ \\
\hline Pendidikan & $0.062^{* *}$ & 0.255 & 0.168 \\
Pekerjaan & 0.854 & 0.130 & $0.098^{* *}$ \\
Pendapatan & 0.104 & 0.762 & $0.09^{* *}$ \\
Jarak ke hutan & 0.388 & 0.132 & $0.063^{* *}$ \\
Kepemilikan lahan & 0.937 & 0.507 & 0.132 \\
\hline * taraf nyata 5\% & & & \\
**araf nyata 10\% & & &
\end{tabular}


masing-masing nilai $P$ value sebesar 0.104 dan 0.762 . Desa Batununggal memiliki nilai $P$ value sebesar 0.09 yang berarti pekerjaan responden di desa tersebut memiliki hubungan dengan kejadian kebakaran hutan pada taraf kepercayaan 90\%. Tentunya ini berkaitan dengan mata pencaharian di Desa Batununggal sekitar $50 \%$ adalah petani. Hal ini diduga berkaitan dengan dengan penyiapan lahan dengan pembakaran sebelum melakukan penanaman. Tingkat pendapatan di Desa Batununggal memiliki hubungan dengan kebakaran hutan sedangkan tingkat pendapatan di kedua desa lainnya tidak memiliki hubungan kebakaran hutan. Nilai $P$ value di Desa Batununggal sebesar 0.098. Desa Batununggal memiliki responden dengan tingkat pendapatan cenderung lebih rendah dibandingkan kedua desa lainnya.

\section{Hubungan antara aksesibilitas dengan kejadian kebakaran hutan}

Berdasarkan hasil uji Chi Square (Tabel 1), menunjukan bahwa Desa Batununggal merupakan satusatunya desa yang memiliki hubungan antara aksesibilitas dengan kejadian kebakaran hutan. Nilai $P$ value desa tersebut sebesar 0.063 yang berarti bahwa aksesibilitas mampu mempengaruhi kejadian kebakaran hutan pada taraf nyata $10 \%$. Desa batununggal memiliki aksesibilitas yang baik dengan jarak yang dekat dibandingkan dengan desa lain. Desa Hegarmanah dan Desa Cicantayan memiliki masing-masing nilai $P$ value sebesar 0.388 dan 0.123 .

\section{Hubungan antara luas kepemilikan lahan dengan kejadian kebakaran hutan}

Berdasarkan hasil uji Chi Square (Tabel 1), menunjukan bahwa luas kepemilikan lahan di ketiga desa tidak memiliki hubungan dengan kejadian kebakaran hutan. Nilai $P$ value pada masing-masing Desa Hegarmanah, Desa Cicantayan dan Desa Batununggal sebesar 0.937, 0.507 dan 0.132 . Responden di ketiga desa hanya sedikit yang memliki lahan hal tersebut mempengaruhi nilai $P$ value yang dihasilkan.

\section{SIMPULAN DAN SARAN}

\section{Simpulan}

Kejadian kebakaran hutan yang tertinggi selama lima tahun terakhir (2011-2015) adalah pada tahun 2015. Faktor curah hujan merupakan salah satu yang mendukung terjadinya kebakaran di Hutan Pendidikan Gunung Walat. Pada tahun 2015 curah hujan tahunan di Cibadak tergolong tinggi namun terdapat bulan-bulan kering yang sangat panjang pada tahun tersebut meningkatkan potensi terjadinya kebakaran hutan.

Berdasarkan hasil uji Chi Square, Desa Batununggal faktor pendidikan, mata pencaharian dengan mayoritas petani, pendapatan yang rendah dan aksesibilitas yang baik dan jarak yang dekat dengan pemukiman memberikan pengaruh terhadap kejadian kebakaran hutan.

\section{Saran}

Pihak Hutan Pendidikan Gunung Walat sebaiknya melakukan penyuluhan mengenai pencegahan kebakaran hutan dan lahan lebih intensif, membuat papan peringatan terkait kebakaran hutan, membangun menara pantau dan melengkapi sarana dan prasarana alat pemadaman kebakaran hutan dan lahan.

\section{DAFTAR PUSTAKA}

Brown AA, KP Davis. 1973. Forest Fire Control and Use. New York (US): Mc.Graw Hill Book Company Inc.

CIFOR. 2006. Penyebab dan Dampak Kebakaran Hutan dan Lahan di Indonesia. http://www.cifor.org. Dikutip tanggal 22 Mei 2016.

Harianto. 2001. Persepsi, sikap, dan perilaku masyarakat terhadap air sungai [disertasi]. Bogor (ID): Institut Pertanian Bogor.

[Kemenhut] Kementrian Kehutanan. 2014. Statistik Kementrian Kehutanan tahun 2013. Jakarta (ID): Kementrian Kehutanan.

Schmidt FH, Ferguson JH. 1951. Rainfall Types Based on Wet and Dry Period for Indonesian With Wester New Guinea. Jakarta (ID): Kementrian Perhubungan Djawatan Meteorologi and Geofisika. Versi 2. No. 42.

Septicorini EP. 2006. Studi Penentuan Tingkat Kerawanan Kebakaran Hutan di Kabupaten Ogan Komering Ilir Propinsi Sumatera Selatan [skripsi]. Bogor(ID): Institut Pertanian Bogor. Tidak diterbitkan.

Silalahi U. 2012. Metode Penelitian Sosial. Bandung (ID): PT. Refika Aditama.

Singarimbun M, Sofian E. 1995. Metode Penelitian Survei. Jakarta (ID): LP3ES.

Sumantri. 2003. Metode Pencegahan Kebakaran Hutan. Pengetahuan Dasar Pengendalian Kebakaran Hutan. Bogor (ID): Fakultas Kehutanan IPB. Hlm 195-198.

Supangat, Andi. 2010. Statistika dalam kajian deskriptif, infrensif dan nonparametik. Jakarta (ID): Kencana.

Suratmo FG, Husaeni EA, Jaya INS. 2003. Pengetahuan Dasar Pengendalian Kebakaran Hutan. Bogor (ID): Fakultas Kehutanan IPB.

Suyanto S, Applegate G. 2001. Akar penyebab dan dampak kebakaran hutan dan lahan di Sumatera. Di dalam: Suyanto S, Permana RP, Setjono D dan Applegate G, editor. Prosiding Seminar Sehari Hasil Penelitian Kebakaran Hutan dan Lahan di Sumatera. Bogor (ID): ICRAF

Syaufina L. 2008. Kebakaran Hutan dan Lahan di Indonesia. Malang (ID): Bayumedia. 